\title{
Reflections on migrant and refugee health in Malaysia and the ASEAN region
}

\author{
Nicola S. Pocock ${ }^{*}$, Rapeepong Suphanchaimat ${ }^{2}$, Chee Khoon Chan ${ }^{3}$, Erwin Martinez Faller ${ }^{4}$, Nicholas Harrigan $^{5}$, \\ Veena Pillai ${ }^{6}$ and Kolitha Wickramage ${ }^{7}$
}

From Migrant and Refugee Health in Malaysia and the ASEAN region

Kuala Lumpur, Malaysia. 09-10 November 2017

\begin{abstract}
Migrants and refugees face challenges accessing both healthcare and good social determinants of health in Malaysia. Participants at the "Migrant and Refugee Health in Malaysia workshop, Kuala Lumpur, 9-10 November 2017" scoped these challenges within the regional ASEAN context, identifying gaps in knowledge and practical steps forward to improve the evidence base in the Malaysia.
\end{abstract}

Keywords: Migrant health, Refugee health

\section{Introduction}

Globally, there were an estimated 258 million international migrants in 2017, 80 million of whom resided in Asia and $42 \%$ of whom were female [1]. There were an estimated 150 million migrant workers worldwide in 2013 [2]. With accelerating population movement worldwide, "migration is not a problem to be solved but a reality to be managed" [3].

Malaysia hosts an estimated 4-6 million documented and undocumented migrant workers mainly in construction, agriculture, manufacturing and services and domestic work [4]. Malaysia also hosts a registered refugee population of 152,000 mainly from Myanmar [5], and is a destination country for human trafficking.

To examine migrant health in this context, UNU-IIGH organized a 2-day invitation-only workshop on Migrant and Refugee Health in Malaysia on 9-10 November 2017. Over 40 participants from industry, medical professions, civil society and academia in Malaysia attended, including regional speakers presenting case studies of migrant health inclusion from Thailand's Ministry of Public Health $(\mathrm{MOPH})$ and the International Organization for Migration (IOM) as well as several NGO service providers in

\footnotetext{
* Correspondence: nicola.pocock@unu.edu

${ }^{1}$ United Nations University International Institute of Global Health, Kuala

Lumpur, Malaysia

Full list of author information is available at the end of the article
}

Malaysia and Singapore. The workshop aimed to identify gaps in knowledge and promising interventions or policies to improve migrant and refugee health in Malaysia. In this short report, we identify key lessons from the workshop that can inform the direction of future research and practice for migrant health in ASEAN.

\section{Occupational and mental health needs}

Occupational health and mental health needs among migrant workers are many, with evidence severely lacking in this area. High prevalence of workplace accidents among migrant workers indicated a need for better enforcement of Occupational Safety and Health (OSH) laws. Nepali migrants are the second largest group among documented migrants in Malaysia after Indonesians, with an estimated 566,184 present in the country in June 2015 [6]. Nepali migrants have high death rates in Malaysia, with an average of one worker dying a day in recent years [7], which warrants further investigation. Preliminary results from an ongoing study presented at the workshop indicated that cardiovascular and suicide cases were the leading fatalities reported to the Embassy of Nepal in 2015. About $80 \%$ of deaths underwent medically certified post-mortems, but questions remained about the accuracy of causes of death information for the more ambiguous categories. 
Asylum seekers and refugees had high prevalence of common mental health disorders including depression, anxiety and PTSD, linked to past trauma and particularly torture among Sri Lankan refugees. Sources of stress among a small sample of migrant workers in the Klang Valley included heavy workloads and insufficient time to complete tasks, no feedback permitted on workplace policies and workplace conflict.

Suggestions to improve data accuracy included having health attachés in sending country embassies to enhance cause of death reporting. Policy suggestions included continuous OSH training for migrant employees and permitting refugees to resettle and work, which would provide needed material income and a sense of hope and purpose.

\section{Needs of detained migrants, refugee women and trafficked children}

Health needs of migrants in Immigration Detention Centres (IDCs), refugee women and trafficked children in Malaysia were shared by panelists working in service provision and advocacy. Methods for improving living standards and hygiene among detainees included installing ventilation fans and washing machines in one detention center. Community activities with Rohingya women and children included religious and English classes. Addressing child marriage in the community is challenging when male guardians believe girls will be better protected if they are married. When stateless and refugee children and adolescents lack access to education it denies them hope for a better future while severely constraining their work options. The prevalence of sexual exploitation and baby selling raised questions about how to improve children protection in Malaysia.

Equal protection of children regardless of nationality and enabling stateless and refugee children access to education and healthcare were suggested key policy changes for the next 5-10 years. In IDCs, adequate medical attention, sanitation, water and food, as well as enhanced NGO-Immigration-MOH collaborations, could help to improve detainee's health.

\section{Wider determinants of migrant health}

Wider determinants of migrant health were discussed. Hunger and lack of micro-nutrients in diets and reliance on fast food were key problems among daily crossborder Malaysian migrant youth to Singapore. In a preliminary survey with migrant workers in the Klang Valley, the majority (58\%) were food insecure. Food insecurity was higher among Burmese migrants, and overweight was more frequently observed among Bangladeshi and Nepali participants [8]. Food and nutritional practices were tied to mobility and limited income, where feeling fullest at low cost was important.
A mixed methods study of return Mekong migrants in Thailand and Malaysia was presented by the ILO. The Migration Outcomes Index evaluates socio-economic benefits of labour migration [9]. Vietnamese migrants had better outcomes linked to higher skill levels and longer periods spent working abroad compared to migrants from Cambodia, Laos and Myanmar. Low wage levels were described as a key stressor among migrant workers, and participants discussed how ensuring protection for migrant's wages and working conditions would avert a "race to the bottom" for Malaysian workers' conditions. Interventions suggested to improve socioeconomic returns included job skills training, receiving the minimum wage, helping migrants to avoid large debts and help to secure jobs upon return to home countries.

\section{Healthcare financing for migrants and refugees}

Financing arrangements for health insurance schemes for migrants and refugees differ between Thailand and Malaysia, the two main destination countries for migrants in ASEAN. For Thailand, the Ministry of Public Health provides the Health Insurance Card Scheme (HICS) covering both an estimated 1.5 million formerly undocumented migrant workers who then registered with the government (semi-legalized migrants) as well as undocumented migrants and their dependents [10]. Established in 2004, the benefits package has expanded over time. To date, the scheme provides a wide range of care, from basic outpatient and inpatient services, to high cost treatments like antiretroviral therapy for HIV/ AIDS. Nevertheless, while the HICS has significantly increased utilization of inpatient and outpatient care among migrant workers, utilization rates are much lower than among Thai citizens enrolled in the Universal Coverage Scheme (UCS) [10]. Since 2014, undocumented migrants and their dependents are required to register at One Stop Service Centres (OSSC), which required the Ministry of Public Health (MOPH), Ministry of Interior (MOI) and Ministry of Labour (MOL) to operate together in designated places in each province. Upon registration, migrants then obtain work permits issued by the MOL, acquire the HICS insurance card provided by the $\mathrm{MOPH}$, and undertake Nationality Verification (NV) managed by the MOI. While Thailand's inclusion of migrants in its public insurance scheme with a somewhat similar benefits package to Thai citizens is widely lauded, the country still faces several challenges. For instance, the health insurance unit's capacity to regulate and monitor the scheme is limited. The NV process is extremely slow, rendering a number of registered migrants as undocumented again when they fail to complete the process [11]. Panelists and participants reflected on how the HICS and the OSSC periodic migrant registration amnesties were temporary solutions, suggesting that solely 
providing health insurance for migrants was insufficient. Supporting policy initiatives that address migrants' health holistically, including remedying precarious legal status, should be implemented.

In Malaysia, documented migrant workers are enrolled in a mandatory health insurance scheme (Skim Perlindungan Insurans Kesihatan Pekerja Asing, SPIKPA) offered by a consortium of private insurers overseen by the $\mathrm{MOH}$. In one analysis, migrants with a minimum wage income of MYR1000/month (US\$254/month) were found to be paying a de-facto income tax rate of $10-21 \%$. This includes an annual migrant worker levy (MYR410-MYR2500/year depending on work sector) (US\$104-US\$635/year) [12], levied at various times on employers or employees, depending on shifting government policy imperatives. The de-facto tax rate, similar to what high-income professionals pay, raised the question of whether migrants should have more generous (quasi-citizenship) social entitlements. Healthcare access and disease control among the large pool of undocumented migrants is another urgent policy priority. In face of ever increasing hospital charges for foreign patients, UNHCR Malaysia and RHB Bank have partnered to create an innovative private health insurance scheme, REMEDI. Partnering with telecommunications companies to design and roll out insurance products could enhance uptake among refugees.

\section{Research ethics, policy translation and bridging the academia-NGO divide}

Presentations on research and evidence needs and policy translation for migrant health underscored the need for better research and ethical practices. Having no

available ethics boards to evaluate study protocols of independent researchers, NGOs, international agencies and private companies was a concern. Existing ethics boards have limited knowledge or capacity to address research on vulnerable populations. Some existing ethics boards and processes are biased towards large-scale, funded research, making research on vulnerable populations by less resourced researchers difficult. Ethical considerations discussed included informed consent processes which recognize the power dynamic between migrants/refugees and researchers, who are seen as authority figures. The principle of beneficence, i.e. explicit benefits from participating in research, must be considered when designing research studies. Implementation studies tied to service provision were one way to realize beneficence. Equally important is non-maleficence, i.e. doing no harm, for example not re-traumatizing participants through sensitive phrasing of questions.

An example of translating research to practice was presented, whereby a mental health survey with foreign domestic workers in Singapore was used to develop a pilot peer-to-peer Cognitive Based Therapy (CBT) intervention with this group. The program was well received but challenges included tracking outcomes and having a longer training period for peer counsellors. Bridging the academic-NGO divide is challenging. The many bad experiences researchers and NGOs have of each other can be mitigated by acknowledging different cultures and interests (e.g. academics for scientific publications, NGOs for rapid research which can be used for advocacy) as well as understanding that such partnerships are dialogues, with neither side having all of the answers [13].

\section{Discussion and ways forward}

Engaging with regional and global networks for (migrant) health equity will be important to drive and sustain research and policy agendas. Networks presenting at the workshop included the Coordination of Action Research on AIDS and Mobility (CARAM Asia), the Equity Initiative in China and ASEAN, and the Migration Health and Development Research Initiative (MHADRI) global network [14]. Despite large flows of international migrants, just $6.2 \%$ of the 30,000 peer-reviewed articles over the past 16 years have focussed on migrant workers (as opposed to refugees or displaced populations), according to a bibliometric analysis conducted by MHADRI academics commissioned by IOM [3]. Research gaps on occupational and mental health issues among migrant workers persist. Partnering with industry, such as Sime Darby who are leading the way in external engagement with academia and civil society on migrant worker wellbeing initiatives, is one way to facilitate evidence translation to policies and programs. The newly established Migrant Workers Health Research Network (Mig-Whealth) of faculty and students at Management \& Science University in Malaysia provides a model of research partnership with CSOs and migrant workers to conduct research on their health.

Systems thinking can help researchers and policymakers to identify potential negative consequences from policy change. Systems thinking can be applied to complex situations like migration, by identifying positive or negative relationships, balancing or reinforcing feedback loops, virtuous or vicious cycles, that are inherent in the systems we live and work in [15]. To cite one example, after migrants initially entered Europe on sturdier wooden boats, authorities responded by rescuing migrants and destroying boats to deter smugglers, who responded by using flimsier and cheaper rubber dinghies and by abandoning migrants on dinghies at sea, knowing that the European coastguard would rescue them [16]. As mentioned at the workshop, we need conceptual frameworks that consider how the dynamics of human mobility affect population health broadly, including the 
health of citizens in receiving countries, and differences in healthcare entitlements by migrant categories and legal status in different contexts. Holistic conceptual frameworks can inform the design of empirical studies and highlight research and policy gaps. Beyond identifying vulnerabilities, we should focus on resilience and positive health trajectories of migrants. Effectively 'managing' migration health involves mitigating vulnerabilities and risks and enabling positive impacts on population health.

Practical next steps elaborated at the workshop centred on the need for better ethical practices and critical engagement of migrant workers and diverse stakeholders in research design. Several stakeholders are exploring the feasibility of establishing a cross-institutional Ethics Review Board (ERB) for migrant and refugee health research in Malaysia. MHADRI's bibliometric analysis will be made publicly available for researchers to consult before they conduct their own primary studies, based on evidence gaps, to avoid duplication and overlap.

\section{Conclusion}

We hope that this report, while focussed on a workshop conducted in Malaysia, provides insight into migrant and refugee health in other settings. Health status is not a single destination and we must address health inequities created by power differentials, inequitable policies and unequal economic conditions and opportunities including among migrants. We encourage formation of critical coalitions in other countries around migrant health and generation of high quality evidence that can inform interventions. We also caution that evidence is not enough: we must go beyond technical challenges and address the adaptive political challenge of migrant inclusion.

\section{Abbreviations}

ASEAN: Association of South East Asian Nations; CARAM Asia: Coordination of Action Research on AIDS and Mobility; CBT: Cognitive Based Therapy; GST: Goods and Services Tax; HICS: Health Insurance Card Scheme; HISPCP: Health Insurance Scheme for People with Citizenship Problems; IDCs: Immigration Detention Centres; IOM: International Organization for Migration; MHADRI: Migration Health and Development Research Initiative; MOl: Ministry of Interior; MOL: Ministry of Labour; MOPH: Ministry of Public Health; NGO: Non-Governmental Organization; OSH: Occupational Safety and Health; OSSC: One Stop Service Centres; REMEDI: Refugee Medical Insurance; SPIKPA: Skim Perlindungan Insurans Kesihatan Pekerja Asing; UCS: Universal Coverage Scheme; UNHCR: United Nations High Commissioner for Refugees; UNU-IIGH: United Nations University International Institute of Global Health

\section{Acknowledgements}

We gratefully acknowledge financial support to organize the workshop from the China Medical Board's Equity Initiative.

\section{Funding}

The publication cost for this article was funded by the China Medical Board's Equity Initiative.

\section{Authors' contributions}

NP drafted the manuscript. RS, KW, CK, VP, NH and EF critically revised the manuscript. All authors read and approved the final manuscript.

\section{Competing interests}

The authors declare that they have no competing interests.

\section{Publisher's Note}

Springer Nature remains neutral with regard to jurisdictional claims in published maps and institutional affiliations.

\section{Author details \\ ${ }^{1}$ United Nations University International Institute of Global Health, Kuala Lumpur, Malaysia. ${ }^{2}$ International Health Policy Program, Ministry of Public Health, Nonthaburi, Thailand. ${ }^{3}$ Centre for Latin American Studies, University of Malaya, Kuala Lumpur, Malaysia. ${ }^{4}$ Migrant Workers Health Research Network, School of Pharmacy, Faculty of Health \& Life Sciences, Management \& Science University, Shah Alam, Malaysia. ${ }^{5}$ Department of Sociology, Macquarie University, Sydney, Australia. ${ }^{6}$ Dhi Consulting \& Training, Kuala Lumpur, Malaysia. ${ }^{7}$ Migration Health Division, International Organization for Migration, UN Migration Agency, Manila, Philippines.}

Published: 24 April 2018

\section{References}

1. UNDESA. International migrant stock: The 2017 revision [Internet]. 2017. Available from: http://www.un.org/en/development/desa/population/ migration/data/estimates2/estimates17.shtml.

2. ILO. ILO Global estimates on migrant workers: Results and Methodology [Internet]. 2015. Available from: http://www.ilo.org/ wcmsp5/groups/public/-\%2D-dgreports/-\%2D-dcomm/documents/ publication/wcms_436330.pdf.

3. Wickramage K. Migration Health: Global Perspective. Presentation at: Health of Migrants \& Refugees in Malaysia Workshop. UNU-\|GH, Kuala Lumpur, Malaysia; 2017.

4. Chan CK. Malaysia: Migration, Rights, and Health Security. Presentation at: New Paradigms for a Changing Migration Landscape Conference to Commemorate International Migrants Day. Bangkok: Chulalongkorn University; 2015

5. UNHCR Malaysia. Figures at a glance [internet]. 2017. Available from: http:// www.unhcr.org.my/About_Us-@-Figures_At_A_Glance.aspx.

6. Jabatan Tenaga Kerja Kementerian Sumber Manusia. Statistik Pas Lawatan Kerja Sementara (PLKS). Putrajaya; 2015.

7. Reporters F. Report: 386 Nepalese migrant workers died here in 2016. Free Malaysia Today [Internet]. 2017 [cited 5 Jan 2018]; Available from: http:// www.freemalaysiatoday.com/category/nation/2017/01/21/report-386nepalese-migrant-workers-died-here-in-2016/.

8. Chan E, Lau X, Faller E, et al. Food security, household income and nutritional status of migrant workers in Klang Valley, Malaysia. 6th med. Heal. Sci. Symp. [internet]. Kuala Lumpur: Management \& Science University; 2016. Available from: https://www.researchgate.net/ publication/304351296_HOUSEHOLD_INCOME_HOUSEHOLD_FOOD_ INSECURITY_AND_WEIGHT_STATUS_OF_MIGRANT_WORKERS_IN_KLANG_ VALLEY_SELANGOR_MALAYSIA

9. Harkins $B$, Lindgren D, Suravoranon T. Risks and rewards: Outcomes of labour migration in South-East Asia [Internet]. Bangkok: International Labour Organization; 2017. Available from: http://apmigration.lo.org/resources/risks-andrewards-outcomes-of-labour-migration-in-south-east-asia/at_download/file1.

10. Suphanchaimat R, Putthasri W, Prakongsai P, et al. Evolution and complexity of government policies to protect the health of undocumented/illegal migrants in Thailand - the unsolved challenges. Risk Manag. Healthc. Policy [Internet]. 2017 [cited 5 May 2017];volume 10:49-62. Available from: http:// www.ncbi.nlm.nih.gov/pubmed/28458588.

11. The Nation. Migrant worker verifications to be extended. The Nation [Internet]. 2017 [cited 13 Feb 2018]; Available from: http://www. nationmultimedia.com/detail/national/30335000.

12. Lokman T. Employers to pay levy for foreign workers from Jan 1, 2018. New Straits Times [Internet]. 2017 [cited 13 Feb 2018]; Available from: https:// www.nst.com.my/news/nation/2017/12/316614/employers-pay-levy-foreignworkers-jan-1-2018.

13. Harrigan NM. Bridging the Divide in Migrant Worker Research - New Naratif. New Naratif [Internet]. 2017 [cited 5 Jan 2018]; Available from: https://newnaratif.com/research/bridging-the-academic-ngo-divide-inmigrant-worker-research/. 
14. IOM. MHADRI Portal [Internet]. Available from: https://migrationhealthresearch. iom.int.

15. Marshall BDL. Contextualizing Complexity: When Are Systems Science Methods Constructive? Am. J. Public Health [Internet]. 2017 [cited 5 Jan 2018];107:1385-1386. Available from: http://www.ncbi.nlm.nih.gov/pubmed/ 28787194.

16. Thompson S, Singhvi A. Efforts to Rescue Migrants Caused Deadly, Unexpected Consequences. New York Times [Internet]. 2017 [cited 5 Jan 2018]; Available from: https://www.nytimes.com/interactive/2017/06/14/ world/europe/migrant-rescue-efforts-deadly.html.

Submit your next manuscript to BioMed Central and we will help you at every step:

- We accept pre-submission inquiries

- Our selector tool helps you to find the most relevant journal

- We provide round the clock customer support

- Convenient online submission

- Thorough peer review

- Inclusion in PubMed and all major indexing services

- Maximum visibility for your research

Submit your manuscript at www.biomedcentral.com/submit
Biomed Central 